\title{
Carbon offsets for conservation and development in Indonesia?
}

\author{
Thomas P. Tomich, Hubert de Foresta, Rona Dennis, Quirine Ketterings, Daniel Murdiyarso, \\ Cheryl Palm, Fred Stolle, Suyanto, and Meine van Noordwijk
}

\begin{abstract}
The logic of the Clean Development Mechanism (CDM) and other such 'carbon (C) offsets' rests on the notion that the opportunity cost of reducing $C$ emissions is lower in developing countries, creating opportunities for mutually beneficial $C$ trading. While the CDM may offer significant gross financial benefits, there has been little analysis of the opportunity costs of foregone resource exploitation and development opportunities. In addition to assessing the potential for net benefits, this paper also considers the practical implications for design and implementation of $C$ offsets for forest conservation and agroforestation in Indonesia. Virtually nothing is known about these administrative factors, and their associated costs, which can also play a decisive role in feasibility of $C$ offset schemes. Data are from field studies in the lowlands of the Indonesian island of Sumatra, where forests and derived land uses are broadly representative of the lowland humid tropical rainforest systems of insular South-East Asia. These data are the basis for assessing the trade-offs between natural forest protection for $C$ sequestration and conversion to other land uses to meet national development objectives that directly affect people's livelihoods. Carbon stocks are analyzed in terms of 'time-averaged' $C$, an indicator developed for this project. Opportunity costs of land-use alternatives are estimated using standard techniques for economic assessment of investment projects in developing countries. The study finds that imputed timber values are a significant share of the opportunity costs of forest conservation, even for conservative estimates of timber prices. The question of compensating for these foregone values raises complex questions regarding the political economy of Indonesia, since property rights over these resources are highly contentious. These controversies over property rights are also examined within the context of recurrent smoke pollution from land fires in Indonesia, that (among other problems) contribute to greenhouse gas emissions. This smoke is symptomatic of deeper political and institutional problems that raise questions about the permanence of $C$ storage through land-use practices in Indonesia. In comparison to forest conservation, $C$ offsets through agroforestation seem more feasible in Indonesia because property rights over timber from planted trees would be easier to establish and enforce than property rights over timber from natural forests. Although results in this paper look promising, there is still much to be learned about implementation costs, even for the 'easier' case of agroforestation.
\end{abstract}

Key words: agroforestry, carbon sequestration, Clean Development Mechanism, Kyoto Protocol, policy reform, sustainable development, tropical forests

\section{Introduction}

Per capita carbon $(\mathrm{C})$ emissions are much higher in the United States and other rich countries of the Organization for Economic Cooperation and Development (OECD) than they are in lowerincome 'developing' countries. This is largely because of differences in consumption of fossil fuels, that (with cement manufacture) account for roughly $80 \%$ of $\mathrm{C}$ emissions. Although

T.P. Tomich is Principal Economist and Global Coordinator of the Alternatives to Slash-and-Burn Programme, International Centre for Research in Agroforestry (ICRAF), Nairobi, Kenya; H. de Foresta is Forest Ecologist and Charge de Recherches, Institute for Research and Development (IRD), Montpellier, France; $\mathrm{R}$. Dennis is a researcher with the Centre for International Forestry Research (CIFOR), Bogor, Indonesia; Q. Ketterings is Assistant Professor, Department of Crop and Soil Sciences, Cornell University, Ithaca, New York; D. Murdiyarso is Deputy Minister, State Ministry for the Environment, Republic of Indonesia; C. Palm is Senior Scientist, Tropical Soil Biology and Fertility Programme (TSBF), Nairobi, Kenya; F. Stolle is a doctoral student in the Remote Sensing Laboratory, Catholic University of Louvain, Louvain-la-Neuve, Belgium; Suyanto is Agricultural Economist, ICRAF, SE Asia Regional Program, Bogor, Indonesia; M. van Noordwijk is Principal Scientist, ICRAF SE Asia Regional Program, Bogor, Indonesia. Corresponding author is T.P. Tomich (t.tomich@cgiar.org). the link is not technologically predetermined, there is a strong positive relationship between $\mathrm{C}$ emissions and income per capita (WRI et al., 1998, p. 344-345). The logic of the proposed Clean Development Mechanism (CDM) in Article 12 of the 'Kyoto Protocol' to the UN Framework Convention on Climate Change (UNFCCC) rests on the notion that the cost of reducing $\mathrm{C}$ emissions is lower in developing countries, creating (at least in principle) opportunities for mutually beneficial $\mathrm{C}$ trading. Beyond opportunities for trading of emissions in the energy and industrial sectors, the Kyoto Protocol also raises the general possibility of offsetting $\mathrm{C}$ emissions with $\mathrm{C}$ 'sinks' in land use, land-use change and forestry (LULUCF). It is not yet resolved whether (much less how) LULUCF activities are included in the CDM.

There are clear benefits for the US in such arrangements. In a recent survey, Cooper $(2000$, p. 165) reported that the marginal costs of meeting Kyoto targets for the US would fall from \$200 per $\mathrm{Mg} \mathrm{C}$ without emissions trading, to $\$ 56$ per $\mathrm{Mg}$ from trade among developed and transitional economies. If trading with some developing countries (China and India) were allowed, the 
marginal cost of $\mathrm{C}$ emission abatement could fall below $\$ 25$ per Mg.

Would payments for $\mathrm{C}$ sinks - at say $\$ 25$ per $\mathrm{Mg}$ - be a good proposition for the people of Indonesia and other tropical developing countries? Some have argued idealistically that 'artificial' distinctions between global environmental interests and regional, national and local concerns impede action (UNDP et al., 1994, p. 5), but the trade-offs among objectives spanning these scales cannot be ignored by negotiators or by people directly involved. Results of the Alternatives to Slash-and-Burn (ASB) program, which is introduced below, indicate that pursuing global environmental interests sometimes involve a high opportunity cost for local people in Indonesia. However, there may also be some scope for finding common ground to couple local development initiatives with global interests in $\mathrm{C}$ sequestration, since, if the possibility of global climate change is realized, its local manifestation may accentuate the frequency and scale of floods, droughts, fires and pest outbreaks (Jepma and Munasinghe, 1998, p. 49). Indeed, quite apart from C trading, the UNFCCC recognizes the 'adaptation' costs developing countries face if likely climate change scenarios are realized. The need for adaptation, of course, feeds back to the purpose of the CDM, which explicitly aims at sustainable development (without defining what 'sustainable' means, or even indicating who decides on the criteria of sustainability).

The benefits of CDM-type arrangements for $\mathrm{C}$ sinks in Indonesia and other tropical countries may yet turn out to be a moot question. No OECD country had ratified the Kyoto Protocol at the time of this writing (January 2001). Prospects for agreement on the CDM seemed particularly poor, in no small part because of unresolved ethical and equity issues (Baer et al., 2000). And the particular question of including C 'sinks' in the $\mathrm{CDM}$ is especially contentious. However, it is not clear whether the failure of negotiations in the Hague in November 2000 signals the end of a process spanning a few years or the beginning of one taking decades. Henry Jacoby, paraphrased in Science (Kerr, 2000, p. 921), noted 'that it took 50 years for the General Agreement on Tariffs and Trade to evolve into the 138nation World Trade Organization. Kyoto might evolve the same way'; and Morgan (2000) has argued that Kyoto is not the only way to proceed, indeed it may not even be the best way ahead, 'The history of international environmental protection shows that effective regimes start slowly. The diplomatic community should work to encourage the growth of local and regional regimes ... . so that they can ultimately coalesce into a comprehensive set of global arrangements'.

With all the uncertainty, it is not surprising that there has been little progress on questions regarding implementation of the CDM raised by Sedjo et al. (1998) and others soon after the Kyoto Protocol was put forward. This paper reports on aspects of ASB research on two types of land use change in Indonesiadeforestation and agroforestation-to identify priorities for action research on these implementation issues. Although there are gaps in our knowledge of technological options and measurement methods, the institutional and policy questions are even more challenging. Regardless of the fate of Kyoto, there would appear to be a role for the international community to support Morgan's (2000) call for efforts to 'speed adaptive learning based on a sharing of experience of early adopters'. But, as will be discussed in the concluding section, whether or not it is in Indonesia's interest to participate in these experiments in institutional innovation depends as much (or more) on the strategies adopted by private firms in OECD countries as on the policies of their governments.

\section{Carbon Offsets for Forest Conservation}

In line with the spirit of the sustainability clause underlying CDM, the goals of the global Alternatives to Slash-and-Burn (ASB) program are to identify means to reduce the rate of tropical deforestation driven by slash-and-burn and to reduce poverty of smallholders dwelling at the forest margins. ASB was formulated as a partnership among national and international institutions to undertake research on sustainable upland systems as alternatives to unsustainable slash-and-burn in various parts of the tropics. Measurement of differences among environmental consequences of the various land uses provides the basis for quantifying major trade-offs involved in land-use change. Among the main goals of ASB was assessment of the implications of alternative land-use practices on 'climate change' drivers ( $\mathrm{C}$ sequestration and greenhouse gas fluxes) and on sustainable development (including growth, poverty alleviation and food security, as well as agronomic indicators of sustainability). Results of these studies, and the new tools developed by ASB to obtain the necessary data, are reported in separate documents (Palm et al., 1998; Tomich et al., 1998a, 1998b, 2001; Vosti et al., 2000).

The island of Sumatra was chosen to represent the lowland humid tropical forest zone in Asia for the global ASB project. Within Sumatra, ASB research to date has focused on two of the five major agro-ecological zones: the broad peneplain zone and the narrow piedmont (foothill) zone (Scholz, 1983; van Noordwijk et al., 1995). The peneplains in particular have been the focus of government-sponsored settlement schemes (called transmigration), road construction, large-scale logging and various large-scale public- and private-land development projects since the 1970s. Because of these activities, little natural forest remains in Sumatra's peneplains. This process of deforestation, which is almost complete in lowland Sumatra, seems likely to be repeated elsewhere in Indonesia. By understanding this process and its consequences in Sumatra, ASB researchers hope to identify policies and technologies that can ameliorate the effects of deforestation and contribute to conservation of the remaining rainforests in Asia.

Sumatra's peneplains are home to millions of small-scale farmers-including indigenous groups, spontaneous migrants and government-sponsored transmigrants-all of whom depend primarily on land converted from forest in order to make a living. Significant numbers also gather products from the forest. Public and private estates (operating forest concessions and plantations of $10,000-300,000$ ha or more) pursue profitable large-scale land uses in the same areas. Large estates and smallholders compete for a limited area of land, which 
contributes pressure for forest conversion. The land uses and management strategies of large-scale estates differ significantly from smallholders' land-use alternatives in their social, economic and environmental impacts.

\section{Sumatran land uses}

Seven 'meta' land uses were selected to organize the national ASB research agendas in a way that would facilitate cross-site comparisons (Table 1). Because deforestation is among the primary concerns of this research, natural forests provide the basic reference point for global environmental concerns. Grasslands and pastures are included as reference points at the opposite ecological extreme. In between, a representative range of five generic upland, rain-fed land-use systems were selected for cross-continent comparisons of alternatives: (1) extraction of forest products; (2) complex multistrata agroforestry systems, also known as 'agroforests'; (3) simple treecrop systems, including, but not limited to, monoculture; (4) crop-fallow systems, which include the textbook version of 'shifting cultivation' or slash-and-burn agriculture; and (5) continuous annual cropping systems, which may be monocultures or mixed cropping. More detailed definitions of these six land uses can be found in Tomich et al. (1998a).

\section{Carbon stocks}

Carbon stocks in above-ground vegetation only are included in this analysis. Carbon in the roots and the topsoil $(0-20 \mathrm{~cm})$ were also measured but were excluded because of the high variability in those data and the relatively small changes in these stocks compared to those of above-ground carbon (Palm et al., 1998). (The systems studied all are on mineral soils; this generalization does not apply to peat soils.) Greenhouse gas emissions (methane and nitrous oxide) were also measured for the same land-use systems as studied for their C stocks. However, these fluxes from living systems are a tiny fraction of the $\mathrm{C}$ release resulting from forest conversion (Tomich et al., 1998a, Part II). The point data from the samples of above-ground $\mathrm{C}$ stocks were used to estimate the 'time-averaged C stock' for major land-use systems (Palm et al., 1998). Land use/cover change can thus be translated into a net release or net storage of $\mathrm{C}$.

C stocks of tree-based land-use systems depend largely on the typical cycle length of these systems, as annual $\mathrm{C}$ increments are similar. Thus, time-averaged $\mathrm{C}$ stocks are similar for forest extraction and long-rotation tree-based systems, such as agroforests (Table 2). However, it must also be emphasized that agroforests and other tree-based systems are not perfect substitutes for biodiversity conservation in natural forests. Indeed, conversion of natural forests to agroforests involves a significant reduction in species richness (Michon and de Foresta, 1995; Tomich et al., 1998a).

\section{Profitability of forest-derived land uses}

ASB methods for profitability estimates apply the 'policy analysis matrix' approach of Monke and Pearson (1989). Each is the present discounted value of estimates of cash flows over 25 years. A real discount rate of $15 \%$ per year was used for the social profitability estimates reported in this paper. Other details are given in Tomich et al. (1998a) and Vosti et al. (2000). Although efforts were made to adjust for trade policy distortions, it was not possible to account for environmental externalities in these social profitability estimates.

At the time of the ASB field studies (in mid-1997) in Sumatra, estimates of returns to land indicate that the textbook 'shifting cultivation' system - upland rice (Oryza sativa L.) followed by bush fallow-was no longer profitable (Table 2). This is consistent with the disappearance of shifting cultivation in most of Sumatra's peneplains. Sustainable forms of continuous foodcrop production may be technically feasible in Sumatra's peneplains, but often are not financially attractive because they require too much labor and too many purchased inputs, as in the case of cassava (Manihot esculenta).

The main land uses of the peneplains-smallholders' rubber (Hevea brasiliensis) agroforests and large-scale oil palm (Elaeis guineensis) plantations and commercial logging-offer higher returns to land than community-based forest management (Table 2). However, these estimates are a lower bound for profitability of community-based forest management, for at least two reasons. First, it was not possible to cover all the myriad commodities collected from the forest by local villagers. Second, because restrictions banning logging by villagers are enforced actively, it was not possible to obtain data about villagers' timber extraction from this forest.

The results for commercial logging also require some explanation. The negative US\$13 $\mathrm{ha}^{-1}$ (all values are in year 2001 dollars) for commercial logging may appear paradoxical, but this is because sustainable logging regulations-if they really are followed-reduce profitability, mainly by slowing timber extraction. However, timber companies can get around these regulatory 'problems'. First, many companies circumvent regulations on timber extraction. Second, these are typically vertically integrated firms, producing products such as plywood for the export market. The best indicator of profitability of these activities by logging companies is the figure of just over US $\$ 875$ $\mathrm{ha}^{-1}$ in Table 2, valued at prices that reflect world prices of forestry products. (Tomich et al., 2001). Although this profitable form of logging probably is not a sustainable form of forest management, logging can (and often is) part of the process of conversion to non-forest land uses that are sustainable. The figure reported here is a lower bound for the profits from clear felling to clear land, and the profits from logging could also be added to the profitability estimates for land uses derived from natural forests, particularly oil palm monoculture, examined below.

\section{Trade-offs between carbon stocks and potential profitability}

Compared to natural forests, both of the forest extraction activities and all the forest-derived land uses studied reduce $\mathrm{C}$ stocks (Table 2). These range from about $30-40 \%$ reductions for extractive activities (community-based forest management and 
Table 1. Major land uses at the forest margins of the peneplains of Sumatra, Indonesia. ${ }^{I}$

\begin{tabular}{|c|c|c|c|c|}
\hline 'Meta' land use & $\begin{array}{l}\text { Corresponding land } \\
\text { use in lowland Sumatra }\end{array}$ & $\begin{array}{l}\text { Type/scale of } \\
\text { operation }\end{array}$ & $\begin{array}{l}\text { Landscape mosaic } \\
\text { context }\end{array}$ & Description \\
\hline Natural forest & Natural forest & $\begin{array}{l}\text { 25-ha fragment within } \\
\text { a logging concession }\end{array}$ & Forest mosaic & $\begin{array}{l}\text { Reference point: primary baseline for assessment } \\
\text { of land-use alternatives. Undisturbed for at least } \\
100 \mathrm{yr}\end{array}$ \\
\hline \multirow[t]{4}{*}{ Forest extraction } & $\begin{array}{l}\text { Community-based } \\
\text { forest } \\
\text { management }\end{array}$ & $\begin{array}{l}\text { Common forest land } \\
\text { of } 10,000-35,000 \text { ha }\end{array}$ & $\begin{array}{l}\text { Indigenous } \\
\text { smallholder } \\
\text { landscape mosaic }\end{array}$ & $\begin{array}{l}\text { Reference point/possible ASB best bet: products } \\
\text { are honey (every } 3 \text { years), fish, petai }\end{array}$ \\
\hline & & & & $\begin{array}{l}\text { Reference point/possible ASB best bet: products } \\
\text { are honey (every } 2 \text { years), fish, petai, rattan and } \\
\text { songbirds }\end{array}$ \\
\hline & Commercial logging & $\begin{array}{l}\text { Logging concession } \\
\text { of } 35,000 \text { ha or more }\end{array}$ & Forest mosaic & $\begin{array}{l}\text { Reference point/best bet from official perspective: } \\
\text { simulation of Indonesian 'sustainable logging } \\
\text { system'; 40-yr cycle }\end{array}$ \\
\hline & & & & $\begin{array}{l}\text { Reference point: based on estimates of actual } \\
\text { harvesting behavior for a concession that recently } \\
\text { has been renewed; } 20-25-\mathrm{yr} \text { cycle }\end{array}$ \\
\hline \multirow[t]{2}{*}{$\begin{array}{l}\text { Complex, } \\
\text { multistrata } \\
\text { agroforestry } \\
\text { systems }\end{array}$} & Rubber agroforests & $\begin{array}{l}\text { Smallholders' plots } \\
\text { of } 1-5 \text { ha }\end{array}$ & $\begin{array}{l}\text { Indigenous } \\
\text { smallholder } \\
\text { landscape mosaic }\end{array}$ & $\begin{array}{l}\text { Indigenous system: forest clearing followed by } \\
\text { upland rice and planting of 'unselected' rubber } \\
\text { seedlings, with natural regeneration of forest } \\
\text { species. This is the dominant smallholder land use }\end{array}$ \\
\hline & $\begin{array}{l}\text { Rubber agroforests with } \\
\text { improved planting } \\
\text { material }\end{array}$ & $\begin{array}{l}\text { Smallholders' plots } \\
\text { of } 1-5 \text { ha }\end{array}$ & $\begin{array}{l}\text { Indigenous } \\
\text { smallholder } \\
\text { landscape mosaic }\end{array}$ & $\begin{array}{l}\text { Possible ASB best bet: forest clearing followed by } \\
\text { upland rice and planting of rubber clones, with } \\
\text { natural regeneration of natural forest species }\end{array}$ \\
\hline \multirow[t]{2}{*}{$\begin{array}{l}\text { Simple treecrop } \\
\text { systems }\end{array}$} & Rubber monoculture & $\begin{array}{l}\text { Smallholders' plots } \\
\text { of } 1-5 \text { ha }\end{array}$ & $\begin{array}{l}\text { Indigenous } \\
\text { smallholder } \\
\text { landscape mosaic }\end{array}$ & $\begin{array}{l}\text { (Formerly) best bet from official perspective: } \\
\text { upland rice and planting of rubber clones, with } \\
\text { intensive use of inputs and labor to prevent } \\
\text { regeneration of natural forest species }\end{array}$ \\
\hline & Oil palm monoculture & $\begin{array}{l}\text { Large-scale private } \\
\text { estate of } \\
35,000 \text { ha or more }\end{array}$ & $\begin{array}{l}\text { Monoculture } \\
\text { plantation }\end{array}$ & $\begin{array}{l}\text { Best bet from official perspective: plantation oil } \\
\text { palm grown in close association with processing } \\
\text { mill (processing not included in the economic } \\
\text { analysis) }\end{array}$ \\
\hline \multirow[t]{2}{*}{ Crop/fallow systems } & $\begin{array}{l}\text { Upland rice/bush fallow } \\
\text { rotation (shifting } \\
\text { cultivation) }\end{array}$ & $\begin{array}{l}\text { Smallholders' plots } \\
\text { of } 1-2{\text { ha } \mathrm{yr}^{-1}}^{\text {, }} \\
\text { often located in } \\
\text { community land }\end{array}$ & $\begin{array}{l}\text { Indigenous } \\
\text { smallholder } \\
\text { landscape mosaic }\end{array}$ & $\begin{array}{l}\text { Reference point: } 1 \text { year of upland rice followed by } \\
\text { bush fallow of } 10 \text { years of more. The dominant } \\
\text { smallholder land use of } 100 \text { years ago, now rare }\end{array}$ \\
\hline & & & & $\begin{array}{l}\text { Reference point: } 1 \text { year of upland rice followed by } \\
\text { a short bush fallow of } 5 \text { years or less. Now found } \\
\text { only in isolated areas }\end{array}$ \\
\hline \multirow[t]{2}{*}{$\begin{array}{l}\text { Continuous } \\
\text { annual crops/ } \\
\text { grasslands }\end{array}$} & $\begin{array}{l}\text { Continuous cassava } \\
\text { degrading to } \\
\text { Imperata cylindrica } \\
\text { grassland }\end{array}$ & $\begin{array}{l}\text { Smallholders' plots } \\
\text { of } 1-2 \text { ha } \\
\text { within large-scale } \\
\text { settlement project }\end{array}$ & $\begin{array}{l}\text { Large transmigration } \\
\text { project divided into } \\
\text { small plots }\end{array}$ & $\begin{array}{l}\text { Reference point: monocrop cassava with little use } \\
\text { of purchased inputs }\end{array}$ \\
\hline & & & & $\begin{array}{l}\text { Reference point: monocrop cassava with intensive } \\
\text { use of purchased inputs }\end{array}$ \\
\hline
\end{tabular}

\footnotetext{
${ }^{I}$ Source: Tomich et al. (1998a).
} 
commercial logging) to $85 \%$ reduction for continuous foodcrops degrading to Imperata cylindrica grasslands. (We explore possibilities for agroforestation of C-depleted Imperata grasslands below.)

Intensified tree-based systems-rubber agroforests planted with improved clones or hybrid oil palm monoculture-combine attractive returns to land with $35-40 \%$ of the time-averaged C stocks of natural forests. Although the profits for conversion of natural forests to these land-use systems are high (especially if timber sales from land clearing are added to the returns to the land use), the possible values of $\mathrm{C}$ sequestration services are even higher. Profitability estimates in Tables 3 and 4 are converted from Indonesian Rupiah to US\$ at pre-monetary crisis exchange rate of Rp 2400 per US\$ of mid-1997, which arguably better reflects a long-run equilibrium exchange rate than the drastically devalued rates that have prevailed during the monetary crisis and ensuing political turmoil.

For natural forest conservation - the 'pristine' forests that are the baseline for ASB analysis-Table 3 presents estimates of C stocks saved and opportunity costs in terms of land-use alternatives, with and without including the value of logging. Opportunity cost in this table means the net present value of foregone returns to the alternative land use. The change in $\mathrm{C}$ stocks in Table 3 is the difference between the above-ground $\mathrm{C}$

Table 2. Carbon stocks and potential profitability. ${ }^{l}$

\begin{tabular}{|c|c|c|c|c|}
\hline Land use & Scale of operation & $\begin{array}{l}\text { Carbon stocks } \\
\text { (above ground): } \\
\text { time averaged } \\
(\mathrm{Mg} \mathrm{ha})\end{array}$ & $\begin{array}{l}\text { Potential } \\
\text { profitability: } \\
\text { returns to land } \\
\text { at social prices } \\
\left(\mathrm{US} \$ \mathrm{ha}^{-1}\right)\end{array}$ & $\begin{array}{l}\text { Employment: } \\
\text { time-averaged } \\
\text { labor input } \\
\left(\text { days } \mathbf{h a}^{-1} \mathbf{y r}^{-1}\right)\end{array}$ \\
\hline Natural forest & 25-ha fragment & 254 & 0 & 0 \\
\hline Community-based forest management & 35,000 ha common forest & 176 & $3-7.5$ & $0.2-0.4$ \\
\hline Commercial logging & 35,000-ha concession & 150 & (13) to 875 & 31 \\
\hline Rubber agroforest & 1-5-ha plots & 116 & 30 & 111 \\
\hline Rubber agroforest with/clonal planting material & 1-5-ha plots & 103 & $97-1510$ & 150 \\
\hline Oil palm monoculture & 35,000-ha estate & 91 & 617 & 108 \\
\hline Upland rice/bush fallow rotation & 1-2-ha plots & 74 & $(75)$ & $15-25$ \\
\hline Continuous cassava degrading to Imperata & $\begin{array}{l}\text { 1-2-ha plots in a } \\
\text { settlement project }\end{array}$ & 39 & $(131)$ & $98-104$ \\
\hline
\end{tabular}

${ }^{1}$ Source: adapted from Tomich et al. (2001), Table 12.2, p. 230-231.

2 At the time of the study in 1997 , the conversion rate was Rupiah 2400 per US $\$ 1$.

Note: numbers in parentheses are negative.

Table 3. Carbon emissions avoided and opportunity cost of natural forest conservation. ${ }^{l}$

\begin{tabular}{|c|c|c|c|c|}
\hline Land use averted & $\begin{array}{l}\text { Carbon stocks } \\
\text { saved (above } \\
\text { ground): change } \\
\text { in } \mathrm{C} \text { time averaged } \\
\left(\mathrm{Mg} \mathrm{ha}^{-1}\right)\end{array}$ & $\begin{array}{l}\text { Opportunity } \\
\text { cost of land-use } \\
\text { averted: change } \\
\text { in returns to land } \\
\text { (US\$ ha } \\
\text { prices) }\end{array}$ & $\begin{array}{l}\text { Payment per } \\
\text { Mg C to offset } \\
\text { opportunity } \\
\text { cost (US\$ } \mathbf{M g}^{-1} \mathrm{C} \text { ) }\end{array}$ & $\begin{array}{l}\text { Maximum } \\
\text { feasible } \\
\text { transaction } \\
\text { costs for world } \\
\text { price of } \\
\text { US\$25 } \mathrm{Mg}^{-1} \mathrm{C}(\%)\end{array}$ \\
\hline $\begin{array}{l}\text { Community-based forest } \\
\text { management }\end{array}$ & 78 & 8 & 0.10 & $>99$ \\
\hline ...with logging & 104 & 883 & 8.49 & 66 \\
\hline Rubber agroforest & 138 & 30 & 0.22 & $>99$ \\
\hline ...with logging & 138 & 906 & 6.57 & 74 \\
\hline $\begin{array}{l}\text { Rubber agroforest with/ clonal } \\
\text { planting material }\end{array}$ & 151 & $98-1509$ & $0.65-9.99$ & $60-97$ \\
\hline ...with logging & 151 & up to 2385 & up to 15.79 & as low as 37 \\
\hline Oil palm monoculture & 163 & 617 & 3.78 & 85 \\
\hline ...with logging & 163 & 1493 & 9.16 & 63 \\
\hline
\end{tabular}

${ }^{1}$ Source: calculated from Table 2.

${ }^{2}$ Currency conversion at Rp 2400/US\$, the rate prevailing in mid-1997 at the time of these surveys. 
stocks of natural forests and the time-averaged $\mathrm{C}$ stocks of the alternative land use.

Based on these estimates of $\mathrm{C}$ stocks saved through forest conservation and the opportunity costs of land uses averted, Table 3 also presents estimates of the farmgate (or forestgate) payment per $\mathrm{Mg}$ of $\mathrm{C}$ needed to offset incentives for forest clearing (simply estimated opportunity cost per hectare divided by the estimated $\mathrm{Mg}$ of $\mathrm{C}$ saved per hectare). Putting aside timber values for a moment, the range of values of $\mathrm{C}$ payments necessary to shift incentives from conversion to conservation varies from $\$ 0.10$ per $\mathrm{Mg}$ for community-based forest management to under $\$ 4$ per $\mathrm{Mg}$ for large-scale oil palm plantations to $\$ 10$ per $\mathrm{Mg}$ for rubber agroforests if much of the productivity growth potential 'on the shelf' can be realized.

Indonesia's lowland dipterocarp forests are a very valuable timber resource, which is readily marketable. Thus, it is not surprising that adding even a lower-bound estimate for the value of logging (the 'with logging' rows in Table 3) has a significant effect on payments per $\mathrm{Mg}$ of $\mathrm{C}$ saved necessary to offset conversion incentives. With a rough proxy for timber included, the range of estimates increase from $\$ 0.10$ to almost $\$ 8.50$ for community-based forest management, to almost $\$ 10$ for oil palm, and to nearly $\$ 16$ per $\mathrm{Mg}$ for intensified rubber agroforests.

The estimates in Table 3 suggest that a world price of $\$ 25$ per $\mathrm{Mg}$ of $\mathrm{C}$ could shift incentives from forest conversion to conservation, if these payments reach the people making the decisions and agreements are enforceable. As will be discussed further below, it is not clear how such transactions would work, and little is known about how much these 'costs of doing business' (transaction costs) would be. The final column of Table 3-which is the difference (in percent) between a notional world price of $\$ 25$ per $\mathrm{Mg}$ of $\mathrm{C}$ and the estimated payment necessary per $\mathrm{Mg}$ - gives some idea of the maximum transaction cost that would still provide a sufficient incentive to local land users. Although the opportunity costs are high, the very large $\mathrm{C}$ increments from saving natural forest bring down the necessary payment per $\mathrm{Mg}$ of $\mathrm{C}$ and leave a margin of $37 \%$ or more for transaction costs.

However, there is little 'pristine' natural forest left to save in lowland Sumatra. Table 4 presents estimates for a more realistic scenario: conservation of community-managed forest. Compared to natural forest, these are partially depleted of $\mathrm{C}$ but they also involve some limited livelihood opportunities. The $\mathrm{C}$ stocks saved in Table 4 are the difference between the lower measured values for community-managed forests and the land use averted. Similarly, the opportunity cost column in Table 4 is the difference between the higher estimate of returns to community-based management ( $\$ 8$ per ha) and the estimate of the present value of the option of converting to rubber agroforest (for smallholders) and oil palm plantation (for large-scale plantation companies). The lower, probably more realistic increment in $\mathrm{C}$ saved in Table 4 (compared to Table 3), results in much higher payment per $\mathrm{Mg}$ of $\mathrm{C}$ required to offset opportunity costs and correspondingly reduces the margin available to cover transaction costs. When timber values are included (the 'with logging' rows), the direct payments required per $\mathrm{Mg} \mathrm{C}$ rise to about \$15-20 for smallholders' conventional agroforests and oil palm plantations.

Most of the calculations in Tables 2, 3 and 4 are based on technologies that predominate currently in Sumatra. However, the possibility of significant yield increases for rubber agroforests exists through adoption and adaptation by smallholders of higher-yielding rubber clones which are on the 'shelf' of available technologies. Field experience still is limited, but prospects are good that profitability of planting clones in smallholders' agroforests exceeds profitability of planting seedlings (the present norm). The question is, by how much could profitability be increased and over what time period? Certainly, within the time frame of $\mathrm{C}$ offset projects, there is

Table 4. Carbon emissions avoided and opportunity cost of community-based forest management. ${ }^{l}$

\begin{tabular}{|c|c|c|c|c|}
\hline Land use averted & $\begin{array}{l}\text { C stocks saved } \\
\text { (above ground): } \\
\text { change in } \mathrm{C} \text { time } \\
\text { averaged }\left(\mathrm{Mg} \mathrm{ha}^{-1}\right)\end{array}$ & $\begin{array}{l}\text { Opportunity cost } \\
\text { of land use averted: } \\
\text { change in returns } \\
\text { to land }{ }^{2} \text { (US\$ ha }{ }^{-1} \\
\text { at social prices) }\end{array}$ & $\begin{array}{l}\text { Payment per } \\
\text { Mg C to offset } \\
\text { opportunity cost } \\
\left(\text { US\$ } \mathrm{Mg}^{-1} \mathrm{C}\right)\end{array}$ & $\begin{array}{l}\text { Maximum feasible } \\
\text { transaction costs } \\
\text { for world price } \\
\text { of US\$25 } \mathrm{Mg}^{-1} \mathrm{C}(\%)\end{array}$ \\
\hline Rubber agroforest & 60 & 23 & 0.38 & 98 \\
\hline ...with logging & 60 & 899 & 14.98 & 40 \\
\hline $\begin{array}{l}\text { Rubber agroforest } \\
\text { with/ clonal planting } \\
\text { material }\end{array}$ & 73 & $90-1502$ & $1.23-20.57$ & $18-95$ \\
\hline ...with logging & 73 & up to 2378 & up to 32.57 & not feasible \\
\hline Oil palm monoculture & 85 & 609 & 7.17 & 71 \\
\hline ...with logging & 85 & 1485 & 17.47 & 30 \\
\hline
\end{tabular}

\footnotetext{
${ }^{I}$ Source: calculated from Table 2.

${ }^{2}$ Currency conversion at Rp 2400/US\$, the rate prevailing in mid-1997 at the time of these surveys.
} 
significant scope for technological change. Results in Table 4 indicate that if available rubber clones were adopted and their yield potential realized by smallholders in rubber agroforests, then the payment required to offset the opportunity cost of this land use could exceed $\$ 30$ per $\mathrm{Mg} \mathrm{C}$.

\section{Knowledge gaps regarding feasibility of $C$ offsets through forest conservation}

Smith and Scherr (2001) observe that 'most pilot forest protection projects have been carried out in remote areas with low population densities, where the rate of deforestation in the absence of the project is moderate or low'. This raises questions about the 'additionality' of the C stocks saved-perhaps they were not at great risk. It also provides a probable explanation why most such projects are in the sparsely populated areas of the Amazon. In densely populated South-East Asia, establishing that natural forests (and hence their $\mathrm{C}$ stocks) are at risk is straightforward, but this also comes with higher opportunity costs of alternative land uses and (probably) higher transaction costs of protecting forests.

Estimates in Watson et al. (2000) indicate that many forest protection projects may be able to supply $\mathrm{C}$ at under $\$ 5$ per $\mathrm{Mg}$. This is consistent with the results in Table 3 , as long as values from logging of timber are ignored. However, even very conservative estimates for timber values for lowland Sumatra raise estimates of necessary payments well above $\$ 5$ per $\mathrm{Mg}$ of C. The data presented here are indicative only, particularly for estimates of values for the extractive activities, i.e., communitybased non-timber forest products (NTFPs) and logging, and there is clearly a need for additional multidisciplinary studies of the direct opportunity costs to smallholders of foregoing forest conversion.

In cases (largely outside Sumatra) where natural forest remains, how much is the timber worth? The ASB results so far suggest the greater payoff to additional information would be improved estimates for timber values, since they are many times larger than the NTFP estimates. These would involve techniques already developed (by ASB and others) to conduct the necessary biophysical and economic analyses. This is straightforward, at least from a static perspective. An equally important, but more difficult, question concerns option values for future development. How, for example, to factor in the option value of technological innovations, such as rubber clones, that are available, but not yet widely adopted?

Although community-based extraction of NTFPs may offer attractive returns to labor far exceeding rural wages (Tomich et al., 1998a), the relatively low returns to land (Table 2), well below those of rubber agroforests, suggest that this is not a feasible alternative for large numbers of people, because there is not enough land for everyone to practice this extensive livelihood strategy. So, in addition to the question of technological change mentioned above, what compensation would be available for the loss of livelihoods and depression of wages that would be transmitted directly through restrictions on access to resources and indirectly through labor markets?
Another difficult question concerns national policy, i.e., who owns the timber? Since colonial times, the policy has been that timber (and other natural resources) are the property of the state. But if local communities are not compensated for timber values, will incentives be sufficient to secure forest conservation? Moreover, in many situations in Indonesia, there are competing claims over these forest lands-between and among large-scale commercial enterprises (loggers and plantation companies) and local communities.

If $\mathrm{C}$ offsets are designed to include the full opportunity costs to these groups, there are additional thorny issues: which group (or groups) to compensate and how to apportion shares among competing claims? Paying two or more parties full compensation for timber and non-timber values plus foregone opportunities for conversion to other uses would undermine the cost-effectiveness of forest conservation projects in Indonesia as a means for $\mathrm{C}$ storage. Yet, as discussed below, failure to address conflicting interests can severely undermine the prospects for 'permanence' of these C stocks.

\section{Smoke Signals (Im)Permanence of C Storage in Indonesian Landscapes}

Differences in time scales of $\mathrm{C}$ storage between fossil $\mathrm{C}$ (eons) and $\mathrm{C}$ in land uses (decades) are a major sticking point on inclusion of terrestrial $\mathrm{C}$ sinks in the CDM, at least under the present Kyoto Protocol requirements that 'certifiable emission reductions' be real, additional, verifiable and permanent. Chomitz (2000) identifies this issue of permanence as the main feature distinguishing LULUCF alternatives from the mitigation measures in the energy and industrial sectors already included in the CDM. Forest and land fires dramatically illustrate the dubious permanence of terrestrial $\mathrm{C}$ sinks. In the case of boreal forests, fire suppression to increase $\mathrm{C}$ storage may even be counterproductive, since these measures ultimately can increase the risk and the intensity of fires through accumulation of fuel loads (Lashof and Hare, 1999, p. 107).

For Indonesia, Dauvergne (1998) estimated that the C emissions of the extraordinary fires in 1997 exceeded the annual emissions of western Europe's power stations and automobiles. The widely cited 1998 study by the Economy and Environment Program for Southeast Asia (EEPSEA) and World Wide Fund for Nature (WWF) estimated that of over \$4.4 billion in damage from Indonesian fires and smoke in 1997, almost $\$ 3.8$ billion $(85 \%)$ was borne by Indonesia itself. Of this, the imputed value of the roughly one gigaton of $\mathrm{C}$ released was by far the biggest cost external to Indonesia (EEPSEA and WWF 1998). The EEPSEA/WWF estimates indicate that Indonesian citizens suffered the most short-term health effects by far ( $\$ 924$ million out of a total estimate of just over $\$ 940$ million; about $98 \%$ ). Although typically labeled a 'regional' or 'transboundary' problem, the most immediate environmental costs are felt by Indonesians. Unfortunately, because of political and social turmoil, it appears that the capacity of the government of Indonesia to act in the national interest on this issue is (at least temporarily) even weaker now than during the previous smoke 'crisis' in 1997/98 (Makarim, 1999). Thus, it would seem that 
this smoke, which first and foremost is a threat to public health in Indonesia, results from lack of political accountability at local and national levels, not simply a lack of international environmental accountability.

What does this emission signal regarding permanence of $\mathrm{C}$ sinks in Indonesia? It is necessary to beware of simple diagnoses for the smoke that has plagued South-East Asia. This year, and every year, many causes underlie thousands of fires in Indonesia. Some of these are accidents, made worse by drought in some years (like 1997/98), but the majority of the fires in Sumatra in 1997 probably were not 'forest fires', nor do many of them appear to have been 'wild fires'. Analysis of satellite images of the 1997 fires in Sumatra show that few of the 'hotspots' in the satellite images - rough indicators of the occurrence of fireswere in natural forests in the peneplains, piedmont or mountain zones; most of the hotspots occurred in swamp forests and logged-over secondary vegetation (Stolle and Tomich, 1999). These areas with the most fires also are the prime areas for conversion. Thus, a large share of the 1997 fires appear to have had a purely practical motive, i.e., that fire is the cheapest way to clear land.

\section{Fire is a tool of sustainable land management}

Slashing and burning is the preferred method of land clearing in the tropics-for smallholders and large companies alikebecause it is cheaper, at least from a private perspective, and easier than available alternatives. In addition, fire eliminates field debris, reduces problems with weeds and other pests and diseases, makes nutrients available in the form of ash and loosens the soil to make planting easier (Ketterings et al., 1999). In some ways it is preferable environmentally compared to some other land-clearing methods. For example, bulldozers and other heavy machinery cause soil compaction and erosion. Fire has many distinct advantages for low-income households: all other methods are more expensive; fire kills crop pests and diseases; and the ash provides much-needed fertilizer. Results of field experiments and surveys in Sumatra by Ketterings et al. (1999) demonstrate the key role that phosphorus $(\mathrm{P})$ plays in resource management. Burning at low or medium intensity releases $\mathrm{P}$ into soil solution, but high-intensity fires reduce $\mathrm{P}$ levels. With greater fuel supply, hence hotter fires, the negative effects of heat on soil mineralogy offset the positive effects of additional ash.

\section{Eliminating smoke does not necessarily cut carbon emissions}

Land-clearing techniques exist that do not produce smoke, including biological methods to accelerate decomposition and various mechanical techniques that chip or shred biomass, either for mulching on the site or for transport off site for disposal or sale. All of these 'no-burn' techniques presently are more expensive than burning. Moreover, as noted above, burning produces many benefits for land users. Research may be able to reduce the economic and technical disadvantages (compared to burning) of certain techniques, such as mulching. If they are feasible, policies to regulate the timing of burning and new techniques for land clearing without burning could-over timeaddress part of the regional smoke problem. However, it must be emphasized that unless a significant portion of the biomass from land clearing is used to manufacture wood products with a long useful life (instead of simply decaying), these measures will only have a short-term effect on $\mathrm{C}$ emissions. Moreover, the attractiveness of technological alternatives to clear land without burning, or the level of subsidies required for adoption of these techniques, also are influenced by national policies, such as timber export taxes, discussed below.

\section{Fire also is a weapon-this smoke signals policy and institutional problems}

Fire is also the tool of choice for land clearing by large-scale agricultural and forestry companies in Indonesia-for many of the same reasons. Large-scale operators have also been known to burn land to drive out smallholders. Smallholders have been known to burn trees established by large-scale operators to retaliate for various injustices. Conflicts over land, resulting from unclear and insecure property rights, and land allocation policies that take too little account of established, albeit informal, local claims are at the heart of this problem. Aside from contributing to social conflict, 'land grabs' by large-scale operators that displace local people also undermine incentives at the community level to prevent, report and fight fires. If landallocation policies concentrate holdings while destroying incentives for 'on-the-spot' fire prevention and management by the local people, this will increase the risk of future smoke 'crises'. And in this sense, the smoke problem can also be seen as a symptom of development strategies that favor large-scale enterprises, while ignoring legitimate local land claims. Addressing this widespread problem of land conflicts in Indonesia's Outer Islands, which contribute to the use of fire as a weapon, could be part of a longer-term strategy to reduce fire risks and to reduce poverty by spreading the benefits of regional development.

\section{Knowledge gaps regarding permanence of carbon offsets in Indonesia}

Real community-level participation and adequate incentives for local people are necessary (but not sufficient) conditions for permanent, secure C storage in Indonesian landscapes. Fay et al. (1998) have documented a pilot effort in this direction, but much remains to be learned about how to establish and replicate local participation and accountability across a huge archipelago characterized by extreme variation in ecology, culture and socio-economic conditions.

Some of Indonesia's fires (and the resulting smoke) are simply a symptom of the high returns to conversion of natural forest described above. Analysis of the 1997/98 fire event in Sumatra suggests that even more smoke is due to the agronomic and economic advantages of fire as a tool in sustainable management of profitable land-use systems. Although none approach the Crichness of natural forests, a number of these tree-based systems that involve periodic clearing, burning and replanting, represent significant $\mathrm{C}$ stocks (Table 2). 
Even if only 'temporary' $\mathrm{C}$ storage spanning $2-3$ decades is possible at the plot level of management of these systems, increasing average $\mathrm{C}$ in the landscape decreases $\mathrm{C}$ in the atmosphere. Additional $\mathrm{C}$ storage results from shifts in management of these heterogeneous land uses. For example, shifting from periodic burning to gap replanting poses greater challenges to measure and verify changes in $\mathrm{C}$ in a cost-effective way than the case of forest conservation discussed above. Also, it is not clear that a 25-30 year cycle of $\mathrm{C}$ accumulation and release at the plot level would meet the permanence requirements of the Kyoto Protocol, even if modifications of such systems resulted in increased C stocks at the landscape level. As one approach to accommodating the Kyoto Protocol's permanence requirements to the realities of smallholder land uses, Chomitz (2000) and others have proposed a ton-year approach, i.e. paying for a flow of $\mathrm{C}$ storage services rather than purchasing $\mathrm{C}$ stocks in perpetuity, to adjust $\mathrm{C}$ credits to duration and also to reward longer deferral of emissions. Thus, if approved within the Kyoto Protocol and if practical feasibility could be established, this approach could be a way to address a number of areas of social, economic and technological uncertainty; in effect, land-use options could be reviewed and adjusted annually. Although the ton-year approach has been a topic of interest to researchers, it has received little attention from politicians and policymakers involved in international negotiations, and little is known regarding the feasibility of implementation.

\section{Carbon Offsets for Development}

A special report of the Intergovernmental Panel on Climate Change (Watson et al., 2000) identified land-use change from cropland and grassland to agroforestry as the largest among potential LULUCF sinks for C globally. There are at least two major barriers to smallholder agroforestation for production of timber and other 'forest' products in Indonesia. First is tenure insecurity for millions of smallholders, because of conflicting claims on land that no longer is natural forest. A long-term process will be needed to develop workable and enforceable agreements between government and local communities regarding land use and production-sharing rights and responsibilities on these lands. The second barrier involves disincentives to smallholder production created by trade and marketing restrictions that undermine incentives regardless of where production takes place, even on private land. The benefits of deregulation of trade and marketing could be felt immediately by millions of smallholders throughout the country, and also represents the easiest step available for immediate reduction in $\mathrm{C}$ emissions from land-use change.

\section{Trade restrictions undermine incentives for agroforestation}

Indonesian forestry policies have been designed to depress domestic prices of timber relative to world prices. Policies that depress prices of wood products increase the 'waste' that must be disposed of by burning or other means. If these policies were eased (or removed), more of the wood felled in land clearing would be sold for timber, thereby reducing the amount that is burned. Significant increases in exports of agroforestry timberfrom wood that currently is wasted-would help Indonesia earn foreign exchange and would reduce $\mathrm{C}$ emissions. Elimination of disincentives to smallholder production by deregulating agroforestry tree species is an important and administratively easy first step toward realizing farmers' potential contributions to meeting growing commercial demand for forest products and to agroforestation of deforested watersheds.

Some of the most complex forestry policy questions concern management of Indonesia's 'old growth' natural forests discussed above. But there are a significant number of agroforestry tree species grown by smallholders (and by largescale estate plantations) that are not natural forest species. Complete deregulation of these agroforestry species thus poses no threat to Indonesia's natural forests, simply because these species are not found in Indonesia's old-growth natural forests. Three categories of agroforestry species can be distinguished to clarify the ecological and economic roles of each species for smallholders:

- Exotic species. None of these species are found in Indonesia's natural forests. Consider rubber wood, which is a substitute for ramin (Gonystylus spp.), one of the most valuable natural forest species. With the depletion of ramin, rubber wood has emerged as an important by-product of natural rubber production. Teak, mahogany and all but one of Indonesia's pines (Pinus merckusii) also are exotics. Although presently grown mainly in large-scale plantations dating from the colonial era, smallholders are interested in planting these species (often beside roads and along fence rows), despite their relatively long gestation periods, because of the high value of their timber.

- Indigenous multipurpose species. Coconut (Cocos nucifera $)$ is the most widespread of these common species. Farmers mainly plant them for non-timber products, but timber is a valuable by-product at the end of the tree's productive life. These species are grown in large quantities by smallholders. Although these are indigenous species, most trees of these species now are planted and only a small proportion of these trees are found in Indonesia's natural forests.

- Indigenous 'pioneer' timber species. Although indigenous to Indonesia's natural forests, these fast-growing, lightloving species specialize in gap filling and, hence, are rare in old-growth natural forests. Their ecological niche also means they are well suited to domestication and planting in farmers' fields.

Current regulations covering trade and marketing of timber and other 'forest' products are designed for natural forest products, but are inappropriately applied to agroforestry products, which are produced from farmers' own labor, land and capital. These policies, which penalize smallholders who grow trees on their farms, include export taxes, natural resource rents and royalties, and administrative procedures for harvesting and transporting timber and other products that have been misclassified as 'forest' products. In addition to being an 
administrative burden, the current complex felling and trading procedures for timber and other products grown on farms create various opportunities for illegal levies. The result is increased marketing costs, which reduce or eliminate farmers' profits. Particularly because these products all require substantial time and investment to produce, inappropriate application of these regulations makes production of agroforestry products, including timber, much less attractive than farmers' other alternatives.

Unlike trees in natural forests, agroforestry species are planted and managed by smallholders just like agricultural commodities. Removing current regulations on harvesting and trade of timber for agroforestry species would significantly improve incentives for development of Indonesia's smallholder farm forestry subsector. This would be an important step toward realizing the potential of smallholders to make a bigger contribution to meeting growing commercial demand for timber. Deregulation of agroforestry species would raise the economic benefits of growing trees on degraded lands and provide a new stimulus for farmers to improve productivity of lands that have been marginal for agricultural production. Therefore, in addition to reducing timber waste (and resulting $\mathrm{C}$ emissions), deregulating harvesting and trade in agroforestry species would help promote agroforestation and thereby produce environmental benefits on a local, regional, national and global scale.

\section{Potential for agroforestation of grasslands}

We now turn to a specific opportunity for agroforestation: Indonesia's extensive alang-alang (Imperata cylindrica) grasslands. More than 8.5 million ha (about $4 \%$ of Indonesia's land surface) are covered by sheet alang-alang (Garrity et al., 1997). Evidence from Indonesia and elsewhere in South-East Asia demonstrates that local people invest on their own to plant trees for timber and other products if they have secure claims over the products; natural risks, such as fire, are not too high; and they have access to markets.

Because changes in land use from grasslands to tree-based systems bring big changes in $\mathrm{C}$ stocks, compensation for $\mathrm{C}$ sequestration through investment to establish trees can significantly raise profitability of grassland conversion. Although there is no substitute for project appraisal for specific settings, significant imputed values of $\mathrm{C}$ sequestration from conversion to Acacia mangium and rubber agroforestry (under technologies, prices and policies prevailing in Indonesia) hold up even for a very conservative estimate of the value of C (US\$5-20 per Mg C).

In fact, while compensation for $\mathrm{C}$ sequestration would raise the profitability of these investments significantly, this compensation would simply raise profits on investments that could have been undertaken anyway (Tomich et al., 1997). The calculations in Tomich et al. (1997) were based on preliminary data on above-ground $\mathrm{C}$ stocks, straight-line accumulation and discounting of annual $\mathrm{C}$ increments, and very conservative estimates for the value of $\mathrm{C}$ sequestration services (US\$5-20 per $\mathrm{Mg} \mathrm{C}$ ). Better data on time-averaged $\mathrm{C}$ (Table 2) and higher values for sequestration services (say US $\$ 25$ per $\mathrm{Mg}$ ) strengthen these conclusions. (Recall that in the profitability estimates in Table 2, foodcrop systems on Imperata grasslands were unprofitable.)

These analyses suggest that, regardless of the future for the $\mathrm{CDM}$, Indonesian initiatives aimed at Imperata grasslands should focus on establishing clear, secure tenure over products of alternative land-use systems and on removal of institutional failures and policy distortions. Under present circumstances of insecure tenure, local people lack incentives to control fires or to plant trees. A policy to establish secure property rights over all products-including the timber-for smallholders who convert plots of grassland by planting and managing trees could be an important first step in addressing the lack of tenure security and in creating incentives for community-based fire control. Without this local cooperation to control fire, sustainable rehabilitation of Imperata grassland is extremely difficult. Profitability of grassland conversion can also be destroyed by a number of policy distortions, including trade and pricing policies that depress output prices. Eliminating current disincentives to Imperata grassland conversion, such as the timber marketing restrictions discussed above, should come before any policy intervention to promote conversion. Property rights over all products, including timber, would create incentives necessary for local people to do the hard work to re-establish trees on grasslands. If tree planting is profitable, local people will do it once they are convinced they will reap the rewards of their work. If it is not profitable, the land will stay as it is.

\section{Concluding Questions}

'Carbon trading', payments for $\mathrm{C}$ sequestration services or for mitigation of $\mathrm{C}$ emissions, under the multilateral $\mathrm{CDM}$ or similar bilateral arrangements may develop as new mechanisms to compensate local communities in order to shift incentives toward more $\mathrm{C}$ storage in tropical landscapes. But many gaps remain, ranging from general questions about the meanings of key terms, for example, whether or not forest conservation and management of soil $\mathrm{C}$ could be included in $\mathrm{C}$ credits for 'deforestation', 'reforestation' and 'afforestation' (Sedjo et al., 1998), to a host of specific operational details of activities for which few countries have had relevant experience, apart from Costa Rica's path-breaking efforts (Chomitz et al., 1999).

ASB researchers are making progress in refining measurements of $\mathrm{C}$ stocks in different land uses at a policy-relevant scale (van Noordwijk et al., 2000), which may be adaptable to establish and verify real changes in C stocks within a project or program for $\mathrm{C}$ offsets. As reported here, ASB has also produced estimates of the 'farmgate' or 'forestgate' direct payments for $\mathrm{C}$ sequestration that would be necessary to shift smallholders' incentives from privately profitable but less C-rich systems to land-use systems that store more C; however, these should be treated as indicative of relative magnitudes rather than definitive results that could be used as a basis for design of interventions. For both forest conservation and agroforestation, studies are needed across a wider range of circumstances found in Indonesia, to improve estimates of the direct opportunity costs of shifting to, or conserving, land uses that can store more $\mathrm{C}$, and to verify the $\mathrm{C}$ increments associated with those changes. 


\section{A key policy question for Indonesians}

Even though available estimates are rough, it is unlikely that further studies will reverse the result reported in this paper that timber values far exceed values of non-timber forest products in Indonesia. Better estimates of opportunity costs are needed for the value of timber in the remaining 'pristine' natural forests and, perhaps more importantly, in community-managed forests. The commercial value of this timber appears to be a decisive element in the cost-effectiveness of $\mathrm{C}$ offsets for forest conservation in Indonesia, compared to other regions (especially the Amazon). The question of timber values also has a deep political dimension in Indonesia, i.e., who owns the timber: the central government, provincial governments, local communities or individuals? This has important implications for implementation of $\mathrm{C}$ offsets for forest conservation. It is up to Indonesians how (and when) this policy question will be answered. In the meantime, $\mathrm{C}$ offsets through agroforestation seem more politically feasible than $\mathrm{C}$ offsets through forest conservation in Indonesia, because property rights over timber from planted trees are easier to establish and resolve than property rights over timber in natural forests.

\section{Institutional questions for designers of $C$ offsets}

Despite the present limits of our information on changes in C stocks and opportunity costs of alternatives, even less is known about the actual 'cost of doing business' (the transaction costs) when smallholder communities (and their heterogeneous landscapes) are involved in $\mathrm{C}$ trade. These costs are important: if they are too high compared to the global price of $\mathrm{C}$ stocks, smallholders' incentives will be inadequate to induce a change in behavior. At present, the transaction costs of trading $\mathrm{C}$ between OECD countries and smallholder communities in the humid tropics may well be higher than transaction costs of $\mathrm{C}$ trading within OECD countries. Is there scope to reduce the transaction costs of trading $\mathrm{C}$ with smallholder communities through 'learning by doing'? Some specific action research questions include:

- What are the relative costs and effectiveness of alternative institutional arrangements (payments for $\mathrm{C}$ in perpetuity versus pay-as-you-go ('ton-years'); direct versus indirect incentives)? It would be desirable to disaggregate components of transaction costs in these studies, i.e., search costs, negotiation and contracting costs, intermediation and marketing costs, monitoring and enforcement costs, and costs of specific interventions to target poor households, to identify the largest elements of costs of trading with smallholders and the best opportunities for cost reduction.

- Is it feasible to develop and use regional baselines to measure and validate $\mathrm{C}$ stocks for specific smallholder landscapes to reduce costs of validation and monitoring?

- Can methods be developed for projecting dynamic baselines-with and without project scenarios that reflect economic and environmental shocks, structural transformation and (possibly) technological change? Can household, regional or quasigeneral equilibrium approaches-extensions of techniques developed by members of the ASB Consortium — be validated and transferred for use by project managers, policymakers and negotiators? Will these simulation approaches be acceptable to $\mathrm{C}$ trading partners?

On these issues, there is much to be gained from an international synthesis to identify methods for accelerating the learning process and thereby bring down the 'transaction costs' of dealing with smallholder communities. There is already experience from the 'activities implemented jointly' (AIJ) projects of the pilot phase of the UNFCCC that could produce relevant lessons (MacDicken, 1999). In their review of AIJ experience in Brazil, India, Mexico and South Africa, Sathaye et al. (1999) conclude that there are major issues to address regarding the institutional basis for establishing additionality of $\mathrm{C}$ (baselines and leakages) and also the additionality of funding (fungibility of ODA versus new money for C offsets). Whether it makes sense for Indonesia to participate in this process of institutional innovation also depends on these questions regarding additionality of $\mathrm{C}$ and funding.

\section{Is the carbon 'additional'?}

It may be too soon to discern whether (or not) the CDM and similar C offset schemes hold attractive opportunities to combine global environmental benefits with development in Indonesia. However, some insights may be gleaned by considering whether examples discussed in this paper might be eligible for $\mathrm{C}$ offset credits regarding three key criteria:

1. the increase in $\mathrm{C}$ stocks must be 'real' (measurable changes) and 'additional' (not an increase that would have happened anyway under 'business as usual');

2. there must be a quantifiable 'baseline' for comparison (some measure of what would have happened without payment of the $\mathrm{C}$ credits); and

3. 'leakages' (offsetting effects that reduce the net change) and 'unintended consequences' (perverse incentives that produce counterproductive results) must both be considered in appraisal of potential projects.

Note also the presumption that projects, bounded in time and space, are the mechanism for implementation. To our knowledge, there has been no discussion of $\mathrm{C}$ credits for broader programmatic approaches (investments in infrastructure or scientific research and development) or of policy reforms. Each of these broader interventions could rival the project approach in potential to shift incentives in favor of $\mathrm{C}$ sequestration.

Consider the timber trade policy reforms discussed above. Eliminating these restrictions would have real, measurable effects, with trade statistics providing a basis for developing a baseline. However, since it appears (at least to us) that it clearly is in Indonesia's national interest to reform these policies anyway, additionality of this $\mathrm{C}$ may be questionable. So, ironically, the measure that would have the most immediate effect on Indonesia's C emissions may not even qualify for C credits.

This points to a more general paradox: no pure 'win-win' opportunity would appear to be eligible, since presumably it would be done anyway. Thus, although Sedjo et al. (1998) 
singled out 'afforestation on low cost lands as among the less expensive alternatives when compared with other greenhouse gas reduction policies', the analysis of smallholder agroforestation of Imperata grasslands summarized above indicates that these investments could be profitable (even without $\mathrm{C}$ credits) if necessary policy and institutional reforms were feasible. (Once such reforms were implemented and all the opportunities that were profitable without $\mathrm{C}$ credits were exhausted, then presumably it would be possible to justify $\mathrm{C}$ credits to promote further grassland conversion.)

In this respect, $\mathrm{C}$ offset projects are no different from any other development project in that effects of policy distortions and institutional weaknesses need to be considered in project appraisal. Ideally, appropriate institutional and policy reforms would precede $\mathrm{C}$ offset arrangements. Indeed, Indonesia could choose to hasten this process in order to prepare for $\mathrm{C}$ offset opportunities. But how likely is that to happen when there are so many other pressing social, economic and political challenges facing Indonesia's policymakers? Although removing existing constraints and disincentives that hamper agroforestation by smallholders would benefit Indonesia, would it not also be justifiable-in terms of real, additional, verifiable $\mathrm{C}$ storage through sustainable development - to fund assistance to break these policy and institutional bottlenecks through $\mathrm{C}$ payments for enabling policy and institutional reforms? Of course, this is precisely the domain of conventional international development assistance by agencies such as the World Bank, regional development banks and the overseas development assistance provided by individual OECD countries, which brings us to our final question.

\section{Will the funds for carbon offsets be 'additional'?}

An international agreement to establish and enforce quotas for the rich countries responsible for most $\mathrm{C}$ emissions would be the driving force behind private-sector participation in $\mathrm{C}$ offset trading, and the source of billions of dollars of additional funding for development. Without binding quotas on $\mathrm{C}$ emissions, the most tangible rationale for additional private finance would fail to appear. In a world without clear prospects for an international agreement like the Kyoto Protocol, would private companies choose to devote significant funds to $\mathrm{C}$ offsets? While there may be some scope for companies to generate tangible returns on these investments through favorable public relations, the concern is that 'funding could be seen as simply fulfilling previously broken promises of aid rather than supplying truly additional support' (Sathaye et al., 1999, p. 193). In a study of AIJ experience by La Rovere (cited in Sathaye et al., 1999, p. 193), the author 'offers a rather dismal description of the whittling down of several hundred million dollars of aid promised by G-7 countries through the Global Environmental Facility (GEF) and other donors. The promised sum was eventually reduced to a fraction of the original commitment'. Agroforestation could be vulnerable target for re-labeling of conventional development assistance as 'clean development'. At best, the results of this re-labeling would be neutral. But, given what promise to be extraordinarily demanding institutional requirements for implementation of CDM-type arrangements, there is a real risk of crowding out initiatives in other sectors (public health, education) that have higher priority in national development strategies. Thus, the bottom line is that significant commitment of additional private funds appears to be necessary if $\mathrm{C}$ offsets are to provide real benefits for Indonesia and other tropical countries.

Acknowledgements. The work reported here is part of the global Alternatives to Slash-and-Burn Program (ASB). ASB was financially supported by the Global Environment Facility (GEF) with UNDP sponsorship and by DANIDA. Additional sources of funding for ASB work in Indonesia include the Asian Development Bank (ADB), the Australian Centre for International Agricultural Research (ACIAR), the Ford Foundation, the governments of Indonesia, Japan, New Zealand, and the United States. This paper draws on Tomich et al (1997, 1998a, b, c), Tomich et al (2001), and a joint CIFOR/ICRAF/UNESCO project on the underlying causes of Indonesia's smoke problems. We have benefited from discussion of these topics with many colleagues, particularly Neil Byron, Kenneth Chomitz, Ken MacDicken, Pedro Sanchez, Tony Simons and Lou Verchot. Suseno Budidarsono did many of the calculations and coordinated the work to produce estimates of returns to land in Table 2 .

\section{References}

1. Baer, P., J. Harte, B. Haya, A.V. Herzog, J. Holdren, N.E. Hultman, D.M. Kammen, R.B. Norgaard, and L. Raymond. 2000. Equity and greenhouse gas responsibility. Science 289:2287.

2. Chomitz, K.M. 2000. Evaluating carbon offsets from forestry and energy projects: how do they compare? Development Research Group, World Bank, Washington, DC. Manuscript.

3. Chomitz, K.M., E. Brenes, and L. Constantino. 1999. Financing Environmental Services: The Costa Rican Experience and its Implications. Development Research Group, World Bank, Washington, DC. Manuscript.

4. Cooper, R.N. 2000. International approaches to global climate change. The World Bank Research Observer 15(2):145-172.

5. Dauvergne, P. 1998. The political economy of Indonesia's 1997 forest fire. Australian J. International Affairs 52(1):13-17.

6. EEPSEA and WWF. 1998. New estimates place damage from Indonesia's 1997 fires at \$4.4 billion. Economy and Environment Program for SE Asia, Singapore, and World Wide Fund for Nature, Washington, DC. Press release 29 May.

7. Fay C., H. de Foresta, M. Sirait, and T.P. Tomich. 1998. A policy breakthrough for Indonesian farmers in the Krui Damar agroforests. Agroforestry Today 10(2):25-26.

8. Garrity D.P., M. Soekardi, M. van Noordwijk, R. de la Cruz, R. Pathak, H.P.M. Gunasena, N.Van So, G. Huijun, and N.M. Majid. 1997. The Imperata grasslands of tropical Asia: area, distribution, and typology. Agroforestry Systems 36(1-3):3-29.

9. Jepma, C.J., and M. Munasinghe. 1998. Climate Change Policy: Facts, Issues, and Analyses. Cambridge University Press, Cambridge, UK.

10. Kerr, R.A. 2000. Can the Kyoto climate treaty be saved from itself? Science 290:920-921.

11. Ketterings, Q.M., T. Tri Wibowo, M. van Noordwijk, and E. Penot. 1999. Farmers' perspectives on slash-and-burn as a land clearing method for small-scale rubber producers in Sepunggur, Jambi Province, Sumatra, Indonesia. Forest Ecology and Management 120:158-169.

12. Lashof, D., and B. Hare. 1999. The role of biotic carbon stocks in 
stabilizing greenhouse gas concentrations at safe levels. Environ. Sci. Policy 2:101-109.

13. MacDicken, K. 1999. Implications of the Kyoto Protocol on forest management in developing countries: Paying for non-commercial forest values. Impacts 3(2):1,3. Newsletter of the BIOTROP-GCTE Impacts Centre for Southeast Asia, Bogor, Indonesia.

14. Makarim N. 1999. Interview by Thomas P. Tomich on 16 April 1999. In T.P. Tomich, D.E. Thomas, and M. van Noordwijk (eds.). Abstracts and Key Policy Issues, Methodology Workshop on Environmental Services and Land Use Change, Bridging the Gap Between Policy and Research. 31 May-2 June. Chiang Mai, Thailand. International Centre for Research in Agroforestry Southeast Asia Regional Programme and Alternatives to Slashand-Burn Indonesia Consortium, Bogor, Indonesia.

15. Michon, G., and H. de Foresta. 1995. The Indonesian agroforest model. Forest resource management and biodiversity conservation. In P. Halladay and D.A. Gilmour (eds.). Conserving Biodiversity Outside Protected Areas. The Role of Traditional Agro-ecosystems. The World Conservation Union, Gland, Switzerland. p. 90-106.

16. Monke, E., and S.R. Pearson. 1989. The Policy Analysis Matrix for Agricultural Development. Cornell University Press, Ithaca, NY.

17. Morgan, M.G. 2000. Managing carbon from the bottom up. Science 289:2285.

18. Palm, C.A., P.L. Woomer, J. Alegre, C. Castilla, K. Cordeiro, K. Hairiah, J. Kotto-Same, A. Moukam, R. Njomgang, A. Ricse, V. Rodrigues, and M. van Noordwijk. 1998. Carbon sequestration and trace gas emissions in slash-and-burn and alternative land uses in the tropics. Alternatives to Slash-and-Burn Phase II Final Report. Alternative to Slash-and-Burn Programme, Nairobi, Kenya.

19. Sathaye, J.A., K. Andrasko, W. Makundi, E.L. La Rovere, N.H Ravindranath, A. Melli, A. Rangachari, M. Imaz, C. Gay, R. Friedman, B. Goldberg, C. van Horen, G. Simmonds, and G. Parker. 1999. Concerns about climate change mitigation projects: Summary of findings from case studies in Brazil, India, Mexico, and South Africa. Environ. Sci. Policy 2:187-198.

20. Scholz, U. 1983. The Natural Regions of Sumatra and their Agricultural Production Pattern: A Regional Analysis. Central Research Institute for Food Crops, Ministry of Agriculture, Bogor, Indonesia.

21. Sedjo, R., B. Sohngen, and P. Jagger. 1998. Carbon sinks in the post-Kyoto world, Parts I and II. Weathervane. Resources for the Future, Washington, DC. Web site http://www.weathervane.rff.org/ features/feature050.html. Viewed 23 March 1999.

22. Smith, J., and S. Scherr. 2001. Capturing the Value of Forest Carbon for Local Livelihoods. Centre for International Forestry Research, Bogor, Indonesia. Manuscript.

23. Stolle, F., and T.P. Tomich. 1999. The 1997-1998 fire event in Indonesia. Nature and Resources 35(3):22-30.

24. Tomich, T.P., J. Kuusipalo, K. Menz, and N. Byron. 1997. Imperata Economics and Policy. Agroforestry Systems 36(1-3):233-261.

25. Tomich, T.P., M. van Noordwijk, S. Budidarsono, A. Gillison, T. Kusumanto, D. Murdiyarso, F. Stolle, and A.M. Fagi (eds.). 1998a.
Alternatives to Slash-and-Burn in Indonesia: Summary Report and Synthesis of Phase II. ASB-Indonesia Report Number 8. International Centre for Research in Agroforestry Southeast Asia Regional Programme and Alternatives to Slash-and-Burn Indonesia Consortium, Bogor, Indonesia.

26. Tomich, T.P., M. van Noordwijk, S.A. Vosti, and J. Witcover. 1998b. Agricultural Development with Rainforest Conservation Methods for Seeking Best Bet Alternatives to Slash-and-Burn, with Applications to Brazil and Indonesia. Agric. Econ. 19:159-174.

27. Tomich, T.P., A.M. Fagi, H. de Foresta, G. Michon, D. Murdiyarso, F. Stolle, and M. van Noordwijk. 1998c. Indonesia's fires: Smoke as a problem, smoke as a symptom. Agroforestry Today 10(1):4-7.

28. Tomich, T.P., M. van Noordwijk, S. Budidarsono, A. Gillison, T. Kusumanto, D. Murdiyarso, F. Stolle, and A.M. Fagi. 2001. Agricultural intensification, deforestation, and the environment: Assessing tradeoffs in Sumatra, Indonesia. In D.R. Lee and C.B. Barrett, (eds.). Tradeoffs or Synergies? Agricultural Intensification, Economic Development, and the Environment. CAB International, Wallingford, UK.

29. UNDP, UNEP, and the World Bank. 1994. Global Environmental Facility: independent evaluation of the pilot phase. United Nations Development Programme, New York, United Nations Environment Programme, Nairobi, and the World Bank, Washington, DC. World Bank, Washington, DC.

30. van Noordwijk, M., T.P. Tomich, R. Winahyu, D. Murdiyarso, S. Suyanto, S. Partoharjono, and A.M. Fagi (eds.). 1995. Alternatives to Slash-and-Burn in Indonesia: Summary Report of Phase 1. ASBIndonesia Report No. 4. International Centre for Research in Agroforestry Southeast Asia Regional Programme and Alternatives to Slash-and-Burn Indonesia Consortium, Bogor, Indonesia.

31. van Noordwijk, M., K. Hairiah, and S.M. Sitompol. 2000. Reducing uncertainties in the assessment at national scale of $\mathrm{C}$ stock impacts of land use change. In D. Magcale-Macandon (ed.). Proceedings of the IGES workshop on GHG inventories for Asia-Pacific region. Institute for Global Environmental Strategies, Hayama, Japan. p. 151-163.

32. Vosti, S.A., J. Witcover, J. Gockowski, T.P. Tomich, C.L. Carpentier, M. Faminow, S. Oliveira, and C. Diaw. 2000. Socioeconomic Issues Linked to Best Bet Land Use Systems. Working group on economic and social indicators: Report on methods for the ASB matrix. Alternatives to Slash-and-Burn Programme, Nairobi, Kenya.

33. Watson, R.T., I.R. Noble, B. Bolin, N.H. Ravindranath, D.J. Verardo, and D.J. Doken (eds.). 2000. Land Use, Land-Use Change and Forestry. Intergovernmental Panel on Climate Change. Cambridge University Press, Cambridge, UK.

34. WRI, UNEP, UNDP, and the World Bank. 1998. World Resources 1998-99. World Resources Institute, Washington, DC, United Nations Environment Programme, Nairobi, United Nations Development Programme, New York, and the World Bank, Washington, DC. Oxford University Press, New York. 